Andreas Wittel,

Department of English and Media Studies, NTU

In ‘Capital \& Class’ 84/Winter 2004:11-30.

Labour, culture, subjectivity: For a political economy from below

It is no secret that the two fields of political economy of communication and cultural studies sit uneasily with each other. Their precarious relationship has been confirmed, documented, and analysed by both sides; the adversarial positions and concepts are well established. Attempts to reconcile political economy with cultural studies dramatically failed and the 'divorce', as Garnham (1995) puts it, has since been accepted apparently without much grief on either side. So is there any need to warm up an old debate, even worse a debate that one of the key contributors already dismissed as 'boring' (Grossberg 1995) a decade ago? Wouldn't it be better to accept the divorce and move on? I am not a relationship consultant and I have to admit that I don't have any ambition to help reconciling two academic fields that don't like each other any more. Disciplines or schools of thought are abstract entities, which don't deserve unconditional loyalty anyway. Moreover, concerns about society, culture, labour, and power are far more interesting than concerns about academic schools studying these issues. ${ }^{1}$

The reasons for disinterring this seemingly dead debate are not romantic but instrumental. At stake is the question of how to study culture particularly in the context of recent changes not only in the cultural industries, but more generally in post-industrial capitalism. At stake are changes in the relationships between (political) economy and culture, between subjectivity and power, and ultimately between labour(-power) and culture such as the rise of immaterial labour. These topics are not only unresolved, they have so far been articulated in a relatively narrow way that does not necessarily take into account recent social and cultural transformations. This article is an attempt to rethink political economy (PE), and more specifically the political economy of communication (PEC), in terms of a broader approach towards labour, culture, and subjectivity. The objective is to identify some problematic issues and areas, which are so far not only under-researched, but under-illuminated. The article consists of four parts. (1) A very brief historical reconstruction of the dispute between PEC and cultural studies is merely an entry point for an argument that seeks to foreground a notion of economic activity through phenomena such as value, desire, knowledge, and affect, in short it seeks to address a problem which crystallizes the problematics of culture and labour. (2) This is followed by an examination of how PE studies labour, and a suggestion to intensify the focus on concrete aspects of labour rather than its abstract constituents. (3) An examination of how PEC perceives the idea of culture makes it clear, that the interest of this discipline remains restricted to the realm of industrialisation of culture, to the 'cultural industries' and its audiences, but does not include an inspection of the growing realm of culturalisation of all

\footnotetext{
${ }^{1}$ Which of course does not mean that the power struggles between academic fields or schools of thought are not relevant. They obviously are, as these struggles for the most appropriate concept, the most appropriate diagnose or interpretation, and the most appropriate cure or problem solving suggestion do not just stay within the walls of ivory towers; they have an impact, they are influential, they co-create reality. Callon (1998) has made this argument with respect to economics and economy.
} 
industries. It will be argued that this black hole is a consequence of and corresponds with the neglect of labour's concrete constituents by PE. (4) The final part consists of some considerations on subjectivity and the possibility of a 'political economy from below' (Negri 1999). There will be no conclusion, this article is written with the intention of opening up certain issues and conventions rather than closing them down.

Defined more narrowly, PE can be described as 'the study of the social relations, particularly the power relations, that mutually constitute the production, distribution, and consumption of resources.' (Mosco 1996) PEC thus studies products or objects of communication as primary resources, such as films, videos, magazines, newspapers, radio programmes, web sites, and audiences. PEC positions itself as the PE of a specific industrial sector, a sector that produces culture, information, communication, and entertainment. PEC studies the so called culture industries, media industries, or creative industries. What was new was the topic of investigation or the object of research. In terms of methodology or epistemology however the approach adopted by PEC was very much in line with PE in general. As will be discussed later, it is this positioning which obstructs the investigation of culture and communication in a broader sense, that is in a way which conceptualises culture and communication not merely as industrial products (objects) or industrial sectors, but as processes relevant for the analysis of work in all industries and all settings of production.

\section{The dispute}

For a long period the main schools of PE, whether the (neo)classical tradition or the critical or (neo)Marxist tradition did not develop a strong interest in the field of culture or communication. Culture and communication were not seen as important categories for the inspection of social relations and power relations. Power was seen to be located in the fields of politics and economy. The first prominent sign of a sea change is perhaps Adorno's and Horkheimer's work on the cultural industry in the 1940s. (Mass)culture was not only seen as industrial, it was seen as powerful in that it obeyed as well as created a single logic: the culture industry produces mass deception and a false sense of happiness, it promotes an affirmative and conformist consciousness thereby disallowing critical thinking. Frankfurt School theorists were perhaps among the first to recognise the growing process by which cultural practices became objects of valorisation of capital. Furthermore, they were perhaps the first to incorporate notions of culture and communications into a critical social theory analysis. They might well be the true founding fathers of PEC.

Both fields, cultural studies and PEC, gained significant recognition with the emergence of the 'cultural turn' in the 1970s and 1980s. What could, should, or might have been a passionate love affair, or at least a happy marriage, soon turned sour. According to Mattelart/Mattelart (1998: 100) the polemic debate began already in the late 1970s. In 1977 Smythe, one of the early political economists of communication criticised media concepts that studied television only in terms of codes, representation, meaning, ideologies, and the reading of signs. Instead television should be studied in economic terms, audiences should be theorized as consumers to be marketed to advertisers. Audiences, so Smythe argued, are the primary commodity of the mass media. Garnham (1979) replied that the cultural and political dimensions of television production and consumption are as important as its economic logic. 
Throughout his career Garnham insisted that (1) the ideological dimension of mass media are as significant as their economic ones, and that (2) the ideological dimension of communication should not be studied on its own, uncoupled from the economic dimension.

During the course of the 1980s and early 1990s it was mainly the PEC side that took issue with certain tendencies that some parts of cultural studies increasingly developed, namely to privilege constructivism and subjectivity over structures, consumption over production, the specific and particular over the general, heterogeneity over homogeneity, description over analysis, meaning over power, race and gender over class, autonomy over domination, complexity over simplicity, and agency over dependency. In the mid 1990s the row between PEC and cultural studies culminated in a short, heated and indeed polemic debate, which was opened by Garnham’s (1995) 'reconciliation or divorce?' question. Grossberg (1995: 80) then rejected 'the invitation to reconcile', claiming that PEC and cultural studies never shared the same agenda, nor did they ever have the same starting point. Other scholars got involved defending each other's standpoints - there is no need to get into more detail.

How can we make sense of this controversy? The latest manifestations of this divide were both polemical and personal, thus avoiding a serious consideration of whether a marriage between both fields/schools is or is not viable. I have already indicated the most important areas of hostility. The dichotomies are multiple, and the perspectives on this dispute are diverse as well. Some theorists (Grossberg 1995) believe that PEC and cultural studies never had much in common, others like Kellner (1998) make a case that the divide is basically false. He sees the PEC approach as deeply rooted in the tradition of social science, whereas the cultural studies approach belongs to a humanities and text-based approach. Nevertheless Kellner is optimistic that the divide could be overcome if only cultural studies would be more sympathetic toward PE approaches, if cultural studies would only synthesise the approaches of the Frankfurt School, British cultural studies, and French poststructuralist theory.

Much of the PEC criticism directed against cultural studies hits a nerve. An issue that hasn't been addressed, however, is whether some dominant epistemological concepts and methodological approaches of both PE and PEC are sufficient to understand the 'social relations, particularly the power relations, that mutually constitute the production, distribution, and consumption of resources.' So this article is not mainly concerned with a critique of cultural studies but with developments in the schools of PE and PEC. Firstly I will look at PE's concept of labour, secondly at PEC's concept of culture and communication. Then I will discuss the idea of a political economy from below.

\section{PE and labour}

O’Brian recently made a call for a greater recognition of agency within the field of international PE. Workers would be largely invisible in this academic discipline. He argues the discipline 'ignores the agency of non-elite groupings of people' and that such an 'omission is a mistake both theoretically and empirically'. (2000: 89) I very much agree with this assessment. In the following paragraphs I want to outline what I consider to be the main reason for this blind spot in PE. Further I want to explain why 
such an approach might have been reasonable at the beginning of industrialisation but poses considerable problems now.

PE is a field with many schools and a variety of approaches and positions. In terms of their perception of the centrality of labour as analytical category they differ hugely. In particular there is a significant divide between the classical and neoclassical PE and the Marxian and neo-Marxian PE. Classical and neoclassical approaches reduce labour to one among other significant factors. Like capital and land, labour is valued for its productivity and for its ability to create value. The key categories for classical $\mathrm{PE}$ however are the market and the individual self-interest. Marx and his followers as most schools leaning toward a critical PE put labour at the centre of analysis. For Marx 'Homo Faber, or man the maker, defined our species-being, specifically the unique integration of conception and execution that separated, in Marx's example, the thinking architect from the institutional bee.' (Mosco 1996: 18) It is perhaps important to add that Marx's general idea of labour is utopian. There should be no alienation, no distinction between architects and institutional bees. His approach to an analysis of labour in (early) capitalism however is based on the abstract qualities of labour.

Marx agreed with Smith that labour is the main source of value. However he identified the commodification of labour as the key to understand capitalism, thus labour as the key to understand exploitation. He distinguished between the use value of labour and the exchange value of labour. The difference between the price of labour in terms of wage and the value of labour creates the surplus value for capitalists. This is how capital is accumulated. The important point is that Marx conceptualises labour mostly as an abstract entity. Marx relates labour to three things. Above everything else he relates labour to capital, value, price, wages, and exchange. This leads to other abstractions, the most important one being the labour market. Secondly he thought of labour in terms of labour processes and forms of the organisation of the labour process. His view was that a commodification of labour leads to rising mechanisation and rationalisation of labour processes. The study of labour in terms of organisation of labour processes might not be quite as abstract as the theorisation of labour as value; still it is an abstraction. So is the development of capitalism: a movement toward abstraction, towards mechanisation and rationalisation. His third important theme of labour is alienation. Alienation is not abstract; on the contrary it is concrete, subjective, and real. Alienation is not about value but about experience, indeed it is the experience of the working class, the institutional bees. It seems however increasingly difficult to merely rely on this concept for an analysis of postindustrial labour, which generally is situated in the domains of the creative, the intellectual, the affective, the cultural. The concept of alienation underrates the possibilities of agency and the liberating potentials of work. Needless to say this does not suggest that so-called creative labour is free from alienation and other kinds of dependencies. But it is perhaps legitimate to assume that the dress of alienation dress doesn't really fit todays' 'creative class' (Florida 2002) the same way it did fit the proletariat of the $19^{\text {th }}$ century. ${ }^{2}$

\footnotetext{
${ }^{2}$ This assumption is strongly contested however and there are good reasons for it. Ross (2000) examines forms of 'mental slavery' in the 'knowledge industries'. Terranova (2000) emphasizes the emergence of new forms of exploitation in the new media industries. Berardi (Bifo) (2001) creates the term 'cognitariat' - a conflation of cognitive worker and proletariat - to characterise the rise of an intellectual proletariat. Finally labels like 'web slaves' and 'net slave', created by practitioners in the
} 
Marx's impact on the following generations of centre to left wing political economists has been profound. His distinction between institutional bees and architects, between execution and conception, marks the beginning of another labour topoi, the division of labour, which is in contemporary PE mostly studied as international division of labour. The methodological approach again is structural; it works through abstraction, classification, and ordering rather than through subjective experience. The final two labour topoi worth mentioning - they emerged well after Marx - are (1) labour regulation and the regulation of the labour market, and (2) labour relations. Again we are dealing with structures and political practices to reshape them.

All these perceptions - labour as value and as market, the organisation of labour processes, division of labour, regulation of the labour market, labour relations - put an emphasis on the instrumental and productive nature of labour, rather than on its expressive and constitutive qualities. Furthermore they focus on the abstract qualities of labour rather than on the actual, concrete, and tangible dimensions. Marx, who originated the difference between abstract and concrete labour, was far more interested in abstract labour. Thus labour remains much in the domain of the base; as part of the base it has not much in common with superstructural phenomena like culture, language, and communication.

It is interesting to note that Habermas, who developed a fundamental critique of Marx's notions of labour by focusing on communication and language, nevertheless remains influenced by Marx's conceptualisation of work and communication. In 'Technik und Wissenschaft als Ideologie' (Technology and Science as Ideology) he says: 'I shall take as my starting point the fundamental distinction between work and interaction.' (1971: 91) I seriously wonder how it was possible to make such a conceptual distinction at a time that is now seen as the beginning of the cultural turn. A theorist who is among the first to understand the growing importance of communication for an analysis of society refuses to acknowledge the intrinsic interactional dimensions of work. For Habermas work still belongs to the instrumental system and interaction to the non-instrumental but communicative life world. The fact that Habermas is most of all a communication theorist certainly indicates that the PEC approach towards labour is not fundamentally different from the main conceptualisations of labour within PE in general. So the critique of a rather undeveloped concept of the cultural and communicative dimensions of work/labour ironically concerns PEC as well, but this issue will be explored in more detail in the following part of the article.

To be clear: This is not a critique of Marx, but of the following adaptations and forms of acceptance of his concept. There has not been a sustained attempt to rethink labour, culture, and communication. These are not essential categories; their meanings as well as their interrelations change over time. It seems fairly obvious that in the middle of the $19^{\text {th }}$ century most types of labour (e.g. coal mining) were less interwoven with cultural knowledge and communication skills than most types of labour today. That is not to say that there didn't (or doesn't) exist a culture of coal mining; of course it does, as every type of labour and every profession brings about a specific set of practices, routines, identities, and symbolic systems. Every industry, organisation, occupation, and work practice brings about cultures understood as 'a way of life' (Williams) or in this respect, a way of work. It merely means that labour 150 years

new media industries, are a further indication that exploitation and alienation have not vanished in the so-called creative industries. 
ago was less infused with cultural knowledge and communication skills. Cultural and communicational expertise were not in the same way intrinsic to work and performance as they are today. Immaterial labour understood as both 'symbolicanalytical services' (Reich 1991) and as 'affective labour' (Hardt 1999; Negri 1999) is necessarily more constituted by communicational practices than material labour. Immaterial labour is built on information and communication practices and on affective investment and human contact. The means of production of manual, material, and industrial labour are machines. The means of production of immaterial and post-industrial labour are culture and communication. In the information age even material or manual labour became increasingly infused with culture, communication, and interaction. A good example would be implementation of teamwork across large parts of industrial spaces in the 1990s. One could even say, responding to Habermas' conceptual differentiation between work and interaction, that in the information or network society work is above all interaction and communication. An example would be the rise of new media industries in the last half of the 1990s. The structure of the net sector can best be understood by looking at work relations and at networking as social practice. In this sector working practices are first of all networking practices (Wittel 2001).

PEC and culture

So far we have seen that although labour is one of the key constituents for political economists, its contemporary uses suffer from a problematic reduction of labour to an abstract category, which brings about a neglect even exclusion of its more concrete, agency- and experience-related aspects. Let's turn the attention toward PEC. Needless to say, culture and communication are as much central constituents for PEC as labour is for PE. I want to argue that the way culture and communication are perceived and conceptualised resonates with and might be a consequence of PE privileging abstract labour at the expense of concrete labour.

Mosco (1996: 72) points out that 'communication and society are mutually constitutive'. He adds however there is a tendency in PEC to concentrate on how communication is socially constructed and to neglect how communication practices construct society. I want to argue that this interest in the constitution and structuration of communication at the expense of an inquiry into the active forces of communication are more than just a tendency; they are deeply embedded in the traditions and the self-consciousness of the discipline. PEC's research fields are either industrial sectors (advertising, film, newspapers etc.), corporations (often transnational ones) or regulatory bodies and institutions. Research topics often focus on questions of ownership and ownership concentration, on processes of diversification, and processes of vertical integration and horizontal integration, on modes of production, on the relationship between production and distribution, on state regulation, and on the relationship between corporate power and state power.

In PEC culture, communication and media are by no means the same thing. However they are all perceived in a similar way. The first two perceptions are obvious and selfevident, the final three are perhaps not as self-evident but also hardly surprising. Firstly, they are perceived as industries, as culture industries, communication industries, and media industries. Secondly, they are perceived as things carrying meaning, as objects, products, and commodities. By nature industries produce commodities. Thus culture, communication and media are perceived as things that can 
be produced, distributed, and consumed. Thirdly, productive and consumptive practices are perceived as strictly separated issues, as distinct and different practises. Fourthly, there is a clear hierarchy between production and consumption. The producers and distributors of cultural commodities and objects of communication are more powerful than their consumers. This perception derives from an epistemological perspective that is based on the notion of causality. It is profoundly influenced by theories emphasising the manipulative effects of the cultural industries (Horkheimer/Adorno) and of an ideological state apparatus (Althusser 1970). Finally, there is a tendency in PEC that cultural commodities and media products with a high reproduction and distribution are seen as more powerful and effective than those with a low reproduction and distribution span.

These five perceptions are not problematic per se. What I consider problematic however are the black holes and the missing perceptions. It is interesting to note how culture and communication are not perceived. In particular three missing perceptions deserve mentioning.

1. Culture and communication are usually studied in terms of structures. These structures refer on the one hand to structures of production and distribution, to modes of production, distribution channels, ownership concentration, product diversification and others, to name a few. On the other hand, they refer to audiences and consumer structures, most notably to class, but recently also to gender and race. Mosco, rethinking PEC, makes a strong case for abandoning the focus on structures for an approach concerned mainly with structuration, an equilibrium between structure and agency, and an interest in processes. This approach however is still in its infancy. Culture and communication have not been rigorously analysed in terms of process. This is not merely about processes of production, this is as much about reproduction and recontextualisation. It is about how culture is moulded, worked upon, modified, engineered, adopted, and adapted. It is about studying culture as a flow, which is constantly moving and changing in shape. It is about how culture is constantly updated.

2. A shift of perspective from structure to process will have profound implications regarding the relationship between production and consumption of culture. As already indicated the main conception is a linear one. Culture or communication are first produced and then consumed. This is very much a one-way street. Production and consumption are clearly separated. This concept makes sense for material objects. A chocolate bar is first produced and then eaten. A table is first made and then bought. Immaterial commodities however do not fit into such a linear concept. Ideas, signs, symbols, and values travel differently, more in a circular way. Meaning is not just produced and then consumed, it is out there and it is permanently reproduced, reshaped, and altered. It is mutually constituted. To give an example: A designer working in the advertising industry does not create a successful logo in a context-free frame of mind. All his knowledge about other logos, other brands, about trends in fashion, and about cultural change in general will have an impact on his design and will influence the outcome of his work (Moor 2004). So it is the consumption of already existing cultural objects that structures the production of the logo. Since the emergence of new media technologies the old boundary between production and consumption becomes even more fragile and blurred. 
3. In the discipline it is a doxa that culture and communication have effects. The media, the cultural or creative industries are seen as powerful actors with an ability to shape mass culture, mass communication, and public consciousness. They can set agendas, dominate discourses, manipulate consumer's minds, and exert ideological control. Thus cultural commodities are powerful too. The higher their distribution the more powerful they are. This knowledge works as doxa, as an uncontested assumption. Now the problem is not that this doxa is wrong - who could argue against, say, the powerful impact of a front-page headline in 'The Sun' on their readers in them making sense of reality. The problem is that an unquestioned assumption about the strong impacts of cultural industries products somehow obscures an interest in the operations of cultural commodities. Indeed how does culture, understood in the broadest sense (encompassing symbols, practices, routines, conventions, ideas, objects, industries, economies etc.) function? How does it work? It is assumed it does, full stop. By the way this interest in the operations of culture is not just lacking in PEC, it has been ignored for a few decades by other disciplines such as anthropology and cultural studies. In US cultural sociology, some scholars have turned their attention to an investigation in the functionality of culture (Schudson 1989; Maxwell 2001; Swidler 2001). Swidler (2001) in particular finds an innovative approach to this problem. She studies the way middle-class American men and women 'think and talk about love to explore larger questions about culture and meaning - how culture actually works when people bring it to bear on a central arena of their daily experience and especially how culture is (or is not) linked to action.' (p1) One might assume than an investigation of the perception(s) of love is of no value for political economists as it is too personal and too mysterious. Swidler however demonstrates how culture permeates ordinary life and how culture is used in the political arena, in religious life, and in other cultural spheres. Even though she does explore this perspective directly from a PE perspective, it becomes quite convincing that even such a personal issue like the perception of love is linked to cultural repertoires, that these repertoires are objects of communication, and ultimately that they are the product of social relation of power.

These three black holes in the study of culture and communication from a PE background - as process, as a circular movement, and as an operation - do have implications for the PEC research field. Basically, it considerably narrows down the scope of research in several ways. The most obvious narrowing down of the field is the restriction to one industrial sector. PEC studies the media industries and sometimes other than mass media organisations within the broader sector of the cultural or creative industries. But there is no significant inspection of other industrial sectors, e.g. agriculture, manufacturing, and finance among others. The interest of PEC is an examination (1) of the production of culture and communication within the cultural industries, and (2) to a much lesser extent of the uses of cultural commodities, which then are always linked to leisure and to audiences consuming mass cultural products. However there is no examination of the use of culture in all industrial sectors. Why only focus on the cultural industries rather than on all industries? Why only focus on the production of culture and communication in the cultural industries and neglect the uses of culture in all industries? The answer lies probably in the epistemological interests of PEC. This interest is directed towards an analysis of the industrialisation and economisation of culture. It is however not directed on the way 
this industrialisation of culture impacts on other industrial sectors, a perspective introduced by Lash/Urry's (1994) study on the economy of sign and design. It is not directed towards an exploration of the processes of a culturalisation of all industries and a culturalisation of the economy. The former phenomenon - the industrialisation of culture - emerged as a process with the rise of fordism. The latter, I would argue, is a more recent phenomenon, a process related to the era of post-fordism. The exploration of a 'cultural economy' recently attracted considerable interest across various disciplines like anthropology, cultural geography, cultural studies, cultural sociology (Ray/Sayer 1999; Crook et al 2000; du Gay/Pryke 2002; Amin/Thrift 2004) and originated perhaps in the work of Baudrillard (1979; 1981; 1993) and Bourdieu (1983; 1984).

Due to the neglect of processes of culturalisation of all industries certain research fields remain untouched. To give an example, PEC has not very much been concerned with corporate culture debates. This field has been left to organisation studies, which in turn is dominated by business studies. Corporate cultures or organisational cultures are produced in order to be used for economic reasons. Often they are produced and used by the same people, by a small elite in organisations that attempt to manipulate and control meaning. An inspection of these practices could and should be highly relevant for both $\mathrm{PE}$ in general and PEC in particular.

\section{Agency, subjectivity, affect}

There is another narrowing down of the field, a second consequence of PEC's black holes in their perception of culture and communication. As long as culture is studied in terms of the industrialisation of culture perspective, agency and subjectivity don't matter much for an analysis of productive processes. In fact agency and subjectivity feature more prominently in the analysis of consumptive practices, that is audiences. If agency matters at all in productive processes, it is the agency of very few powerful people in the media and communications industries like Rupert Murdoch or Bill Gates. A turn of direction with an inquiry into the process of the culturalisation of the economy would allow a strong recognition of agency and subjectivity. I have discussed how PE examines labour and how PEC examines cultures. I argued that in both cases there are significant limitations of the scope of inquiry. Ultimately these limitations originate in a neglect of the subject as a unit of analysis.

Mosco (1996) argues that the chief unit of analysis should not be fully formed structures working on other fully formed structures but processes, processes, which build evolving structures. He refers to Giddens' (1984) theory of structuration. Coming from a perspective concentrating on structures a pervasive theory of structuration needs to be built on preceding knowledge about agency and subjectivity. Being rather an exception within the academic field of PEC is the work of Mattelart and Mattelart, which reveals strong connections between PE and cultural change, and which directly includes the subject as a relevant agent in capitalist societies. Mattelart (1991: 217), using Guattari's notion of capitalist subjectivity, sees culture also as defence mechanism against forms of 'propaganda' and other 'abuses of symbolic power'. Mattelart/Mattelart (1992: 66-71) list several reason for 'the return of the subject', e.g. the growing economic awareness of the relevance of users, and synergies between networks of production, distribution, and consumption, which partly emerge from the politics of decentralisation. Mattelart/Mattelart (1998) introduce both ethnomethodology and symbolic interactionism as theories and 
methods that enable closer inspections of social relationships and the role of the actor. As much as this turn towards social relationships, subjectivity, and agency is a welcoming innovation in the discipline of PEC, it goes only half way. Still production and consumption are analysed as distinct spheres, and subjectivity and agency is once more reserved for consumers, users, and audiences. Recognition of the relevance of subjectivity for the analysis of work and production processes is still lacking.

Let's consider for a moment the complexities of desire. PE strands influenced by Marx have privileged a perspective interested in the social construction and organisation of desires and wants by markets. Similarly PEC, e.g. studies of the advertising industries, investigates desire from a perspective of construction, organisation, and control. This perspective does not allow contemplation about the way desire works, and about desire seen as a force (Deleuze/Guattari 1984). The interest in how desire is produced shadows an interest in how desire produces. Desire however, so much is perhaps widely agreed, it not only a social phenomenon, it is as much a subjective phenomenon. Also widely agreed is perhaps the claim, that an understanding of the functioning of post-industrial capitalist economies is impossible without an understanding of desire. If both statements make sense, then it is fairly safe to conclude that PE and PEC should take into account the subjective dimensions of desire as much as its social dimensions.

'An economy of desire is the order of the day' (Negri 1999: 88). Theorists such as Hardt and Negri (Hardt 1999; Negri 1999; Hardt/Negri 2000) turn their attention towards affective labour. In the capitalist stage of informationalisation, they argue drawing on Spinoza's understanding of affect as the power to act, that affect is one of the crucial constituents of immaterial labour, equal in terms of relevance to the other realm of immaterial labour with its intellectual, informational, analytical, and strategic aspects. Affect here is more than feelings or emotions; it is energy, sensation, a force that drives things, bodily movement and social movements, it is human, it is what keeps everything else alive.

Negri (1999) suggests a change of perspective. Instead of from above, where affect becomes invisible, we should study affective labour from below; instead of structures we should inspect subjectivities. In particular he is interested in the relation between labour, affect, and value. For him affect is always both labour and value. This however means that there is a need for economics to measure the value of affective labour. According to Negri this measuring becomes increasingly an impossible task. Labour itself lies now above and beyond measure, indeed because the affective dimensions of labour are at such a central stage in the information age. In PE, that is from above, the theme of value-affect is so integrated in macroeconomic processes that it is virtually invisible. He gives two examples. (1) The domestic and unpaid labour of women and/or mothers/wives. Value is assumed by stripping it from labour, that is, from affect. (2) The economy of attention. Here affect is part of the economic calculation, affect is invested in the interaction with consumers of services. Labour is subsumed, stripping it from value, that is, from affect.

Negri puts forward two reasons why the possibility of measuring labour-value has declined. Interesting in this context is in particular the first one. As labour became more highly qualified and more complex, it could less and less be reduced to simple calculable quantities any longer. A similar argument, without Negri's epochal claim however, is made by Callon (1998). Everything that is outside these calculable quantities, everything that escapes total framing is what Callon considers to be 
'overflows'. Callon does however not argue for the impossibility of calculating labour, instead he is interested in the difficulties for economics to deal with these overflows.

In fact several objections can be raised against Negri's claim of immeasurability. The most important one is perhaps pointing out to the fact that post-industrial economies, however unstable and contingent they might be, still work in a functional and by and large effective way. So de facto labour-affect is constantly measured. This measuring might get more difficult. It also might be the case that this value needs to be adjusted and readjusted over time, as overvaluation and undervaluation is not exceptional but became highly normal. A good example is the rise and fall of the ICT (information and communication technologies) driven new economy. The initial overvaluation of new economy shares was in fact a misevaluation of the financial worth of certain Internet-related commercial ideas. After a few years of hype the measurement of the value of these ideas has been adjusted rather dramatically. So instead of the claim of immeasurability of labour one could argue instead for a growing difficulty in getting the calculations right.

Whether Negri is right or wrong about the impossibility to measure the value of labour-power is another debate; basically this is a problem for economics. For social science in general and political economy in particular the factual economic evaluation of affective labour raises many issues about the - obviously unequal - distribution of power. Additionally an interest in affect and its forces might well contribute to a deeper understanding of what the so-called cultural economy is about. (Maybe it is about the full incorporation of desire in the economic circulation.) In short, especially interesting seems to me his endorsement of the project for a PE from below. For an understanding of the cultural economy, also called post-industrial or informational economy, 'the order of the day' indeed is the economy of desire, is a subjective concept of labour, a concept that includes culture, communication, affect, and biopower for an exploration of work in all productive activities.

A final remark: such a change of perspective has methodological implications. A political economy from below needs a methodology from below. This is the terrain of ethnographic research. In particular within anthropology both, ethnographies of work and ethnographies of organizations, have become well-established genres with a several decades long tradition. These are often investigations about the micro-politics of power, which can and should be fruitful for PE analysis, even though strong links have never been made. Ethnographically under-researched however is immaterial work. Ethnography is based on observation. Immateriality is obviously not as easy to observe as the material world. Desire is there, but it is not necessarily visible. The same is true for affect, thoughts, ideas, communication, engagement, mediation, and other aspects of immaterial labour. A turn toward immaterial labour might be the biggest challenge, which ethnographies of post-industrial economies have to face.

\section{References}

Althusser, L. (1984) Ideology and ideological state apparatuses. In: Essays on ideology. London: Verso. 
Amin, A. and Thrift, N. (2004) (eds.) Cultural economy reader. Oxford: Blackwell. Baudrillard (1970): Consumer Society

Baudrillard, J. (1981) For a Critique of the Political Economy of the Sign. St. Louis: Telos Press.

Baudrillard (1993): Symbolic Exchange and Death. London: Sage.

Berardi, F.(2001) La fabbrica dell infelicita. New economy e movimento del cognitariato. (The factory of unhappiness). Derive Approdi.

Bourdieu, P. (1984): Distinction. A Social Critique of the Judgment of Taste. London: Routledge.

Bourdieu, P. (1983): Ökonomisches Kapital, kulturelles Kapital, soziales Kapital. In: Kreckel, R. (Hg.): Soziale Ungleichheiten, S.183-198.

Callon, M. (ed.) (1998) The laws of the markets. Oxford: Blackwell.

Cook, I. et al. (eds) (2000): Cultural Turns/Geographical Turns. Harlow: Prentice Hall.

Deleuze, G. and Guattari, F. (1984) Anti-Oedipus. Capitalism and Schizophrenia. London: Athlone.

Du Gay, P. and M. Pryke (eds.) (2002): Cultural Economy. Cultural Analysis and commercial life. London: Sage.

Florida, R. (2002) The rise of the creative class. New York: Basic Books.

Garnham, N (1979) Contribution to a political economy of mass communication. Media, Culture \& Society 1/2.

Garnham, N. (1995) Political economy and cultural studies: Reconciliation or divorce? Critical Studies in Mass Communication, 12: 62-71.

Giddens, A. (1984) The constitution of society: Outline of a theory of structuration. Berkeley: University of California Press.

Grossberg, L. (1995) Cultural Studies vs. political economy: Is anyone else bored with this debate? Critical Studies in Mass Communication, 12: 72-81.

Habermas, J. (1971) Technik und Wissenschaft als ‘Ideologie’. Frankfurt/Main:

Suhrkamp.

Hardt, M. (1999) Affective labor. Boundary 2, 26/2: 89-100.

Hardt, M. and Negri, A. (2000) Empire. Cambridge, Mass: Harvard University Press.

Kellner, D. (1998) Communications vs. cultural studies: Overcoming the divide. http://www.uta.edu/huma/illuminations/kell4.htm

Lash, S. and Urry, J. (1994) Economies of signs and space. London: Sage.

Maxwell (ed.) (2001) Culture works: The political economy of culture. Minneapolis: University of Minnesota Press.

Mattelart, A. (1991) Advertising international: The privatisation of public space. London: Routledge.

Mattelart, A. and Mattelart, M. (1998) Theories of communication: A short introduction. London: Sage. 
Moor, L. (2004) Branded spaces: The mediation of commercial forms. Unpublished $\mathrm{PhD}$ thesis, Goldsmiths College, University of London.

Mosco, V. (1996) The political economy of communication. London: Sage

Negri, A. (1999) Value and affect. In: boundery 2, 26/2: 77-88.

O’Brian, R. (2000) Labour and IPE. Rediscovering human agency. R. Palan, Global political economy: Contemporary theories. London: Routledge, p89-99.

Ray, L. and A. Sayer (eds) (1999) Culture and Economy after the Cultural Turn. London: Sage.

Reich, R. (1991) The work of nations. Preparing ourselves for $21^{\text {st }}$ century capitalism. New York: Knopf.

Ross, A. (2000) The mental labor problem. In: Social Text 63, 18/2:1-31.

Schudson, M. (1989) 'How culture works. Perspectives from media studies on the efficacy of symbols’. Theory and Society 18: 153-180.

Smythe, D. (1977) 'Communication: A blindspot of western Marxism'. Canadian Journal of Political and Social Theory, 1/3.

Swidler, a. (2001) Talk of love: How culture matters. Chicago: The University of Chicago Press.

Terranova, T. (2000) Free Labor. Producing Culture for the Digital Economy. Social Text 63, 18/2: 33-58.

Wittel, A. (2001) Toward a network sociality. Theory, Culture and Society 18/6: 5176. 